\title{
Diode laser-assisted transcanalicular dacryocystorhinostomy: the effect of age on the results
}

\author{
Dacriocistorrinostomia transcanalicular auxiliada por laser de diodo: o efeito da idade sobre os resultados
}

Fahrettin Akay ${ }^{1}$, Abdullah Ilhan ${ }^{2}$, Ümit Yolcu ${ }^{3}$, Fatih C. Gundogan ${ }^{4}$, Yildiray Yildirim $^{1}$, Sami Toyran ${ }^{1}$

\begin{abstract}
Purpose: The aim of this study was to explore the effect of age on the success of transcanalicular diode laser-assisted dacryocystorhinostomy (TCDCR).

Methods: Seventy patients (70 eyes) who underwent transcanalicular diode laser-assisted dacryocystorhinostomy for the treatment of nasolacrimal duct obstruction as a primary surgery were included in this retrospective, nonrandomized study. The patients were divided into two groups according to age. Mean ages were 21.3 \pm 3.3 in group 1 and $60.3 \pm 7.3$ in group 2 . The records of the $3-, 6$-, and 12 -month follow-up examinations were evaluated, and the anatomical and functional outcomes were noted. Functional success was defined as the absence of epiphora as indicated by the patient. Anatomical success was determined as patency of the neo-ostium with irrigation.

Results: At the 3-month follow-up, 67\% cases in group 1 showed anatomical success and $52 \%$ showed functional success; in group 2, the rates were $100 \%$ and $92 \%$, respectively. Functional and anatomical success rates were the same for both the 6 - and 12 -month visits; $46 \%$ in group 1 and $76 \%$ in group 2 . The results in group 2 were significantly better at all three follow-up visits $(p<0.05)$.

Conclusions: This study clearly showed that the older patients experienced better transcanalicular diode laser-assisted dacryocystorhinostomy results than the younger patients. The diminished inflammatory response in the older population may be a possible contributing factor to these results.
\end{abstract}

Keywords: Dacryocystorhinostomy; Diagnostic technique ophthalmological; Lacrimal duct obstruction; Nasolacrimal duct; Silicones; Lasers semiconductor

\section{RESUMO}

Objetivo: O objetivo deste estudo foi explorar o efeito da idade sobre o sucesso de dacriocistorrinostomia transcanalicular auxiliada por laser de diodo (TCDCR).

Método: Setenta olhos de setenta pacientes submetidos dacriocistorrinostomia transcanalicular auxiliada por laser de diodo para o tratamento da obstrução nasolacrimal como cirurgia primária foram incluidos neste estudo retrospectivo, não randomizado. Os pacientes foram divididos em dois grupos segundo a idade. As idades médias foram 21,3 \pm 3,3 no grupo 1 e 60,3 \pm 7,3 no grupo 2. Os registros do acompanhamento pós-operatório aos três, seis e 12 meses, foram avaliados, observando resultados anatômicos e funcionais. Sucesso funcional foi definido como a ausência de lacrimejamento, conforme informado pelo paciente. Sucesso anatômico foi determinado como a permeabilidade do novo óstio à irrigação.

Resultados: Nos três meses de acompanhamento, 67\% dos casos no grupo 1 apresentou sucesso anatômico, e 52\% mostraram sucesso funcional. No grupo 2, as taxas foram de 100\% e 92\%, respectivamente. Taxas de sucesso funcionais e anatômicas foram as mesmas para ambos os seis e 12 meses de visitas: 46\% no grupo 1 e $76 \%$ no grupo 2. Os resultados do grupo 2 foram significativamente melhores em todas as três visitas pós-operatorias $(p<0,05)$.

Conclusões: Este estudo mostra claramente que os pacientes mais idosos apresentam melhores resultados à dacriocistorrinostomia transcanalicular auxiliada por laser de diodo comparados aos mais jovens. A resposta inflamatória diminuída na população mais velha é um possivel fator que contribuiu para estes resultados.

Descritores:Dacriocistorinostomia; Técnicas de diagnóstico oftalmológico; Obstrução dos ductos lacrimais; Ducto nasolacrimal; Silicones; Lasers semicondutores

\section{INTRODUCTION}

Primary acquired nasolacrimal canal obstruction (NLDO), which presents with persistent epiphora and with or without dacryocystitis, is commonly observed in ophthalmology practice. For approximately 100 years, the gold standard treatment for NLDO has been conventional external dacryocystorhinostomy $(\mathrm{DCR})^{(1,2)}$. The goal of DCR surgery is to re-establish tear flow from the lacrimal system into the nasal cavity.

With the advances in laser and endoscopic techniques, endocanalicular and endonasal surgical procedures have become increasingly popular over the past decade. Cosmesis, short recovery time, the lower risk of morbidity, and the lack of impairment of the orbicu- laris oculi pump mechanism are some advantages of minimally invasive surgical approaches such as external DCR ${ }^{(3)}$. Transcanalicular (or endocanalicular) laser DCR (TCDCR) is a recently developed surgical approach for treating NLDO based on the canalization of the upper lacrimal system ${ }^{(4-6)}$. Typically, a laser probe is inserted through both canaliculi and advanced along the nasolacrimal duct to the lateral wall of the nasal fossa, where a transcanalicular nasolacrimal ostium can be created using laser energy. Different types of laser can be used in TCDCR but diode laser is one of the most usefu( ${ }^{(7)}$ because it ablates the bone and the mucosa of the nasal fossa with less collateral damage ${ }^{(8)}$. Different success rates have been reported in various studies ${ }^{(8,9)}$.

This study aimed to investigate the effect of age on the final success rates with TCDCR.
Submitted for publication: September 25, 2014

Accepted for publication: March 14, 2015

1 Ophthalmology Department, İzmir Military Hospital, İzmir, Turkey.

Ophthalmology Department, Erzurum Military Hospital, Erzurum, Turkey.

${ }^{3}$ Ophthalmology Department, Siirt Military Hospital, Siirt, Turkey.

${ }^{4}$ Ophthalmology Department, Gülhane Military Medical Faculty, Ankara, Turkey.
Funding: No specific financial support was available for this study.

Disclosure of potential conflicts of interest: None of the authors have any potential conflicts of interest to disclose.

Corresponding author: Umit Yolcu. Department of Ophthalmology - Siirt Military Hospital - 56100, Siirt - Turkey - E-mail: umit_yolcu@hotmail.com

Approved by the following research ethics committee: Izmir Military Hospital Institutional Ethics Committee. 


\section{METHODS}

Seventy consecutive diode laser DCR operations of 70 patients within a 16-month period were included in this study. The patients were divided into two groups based on age. Group 1 (under 45 years) consisted of 33 patients with a mean age of $21.3 \pm 3.3$ years (range, 20-25); 25 members of this group were enlisted soldiers in the Turkish army. Group 2 consisted of 37 patients with a mean age of $60.3 \pm$ 7.3 years (range, $45-70$ ).

The records of patients who underwent TCDCR as a primary surgery for NLDO at the Izmir Military Hospital between January 2010 and January 2013 were retrospectively reviewed after approval of the study by our Institutional Ethics Committee. The patients, all of whom complained of epiphora, underwent standard ophthalmic examinations, including nasolacrimal drainage system probing and irrigation. Indications for DCR were determined based on a history of epiphora and NLDO diagnosed by the irrigation of the nasolacrimal canal. The patients were referred to an otorhinolaryngologist prior to undergoing surgery to explore any nasal anatomical variations and pathologies that may have complicated the surgeries. Patients with a history of septoplasty, ethmoidectomy, or other nasal surgeries; significant sinus pathologies; septal deviation; concha bullosa; or middle turbinate hypertrophy were excluded. Patients with a postoperative follow-up period of at least 12 months were included. Informed consent was obtained for each patient, and the tenets of the Declaration of Helsinki were followed.

All procedures were scheduled on an outpatient basis. Preoperative screening was conducted for bleeding issues and systemic hypertension. If present, the bleeding tendency and systemic arterial hypertension issues were controlled before the surgery. Diabetic patients were excluded. The surgical procedure was performed under local anesthesia by the same two ophthalmologists (FA and YY).

One hour before the surgical intervention, a mixture of 10\% xylocaine (Xylocaine pump spray 10\%; Astra Zeneca, Istanbul, Turkey) and adrenaline- (Adrenalin 0.5 mg; Osel, Istanbul, Turkey) soaked cotton plugs were inserted into the nasal cavity. The operations were conducted with a transcanalicular 940-nm diode laser (Quanta System, Solbiate Olona, Italy). The inferior and superior puncta were dilated, and a 600- $\mu \mathrm{m}$ laser fiber was passed through the canaliculi up to the sac. A 4-mm, 0-degree, angled, rigid nasal endoscope (Storz, Tübingen, Germany) was introduced into the nasal cavity, and the aiming beam was transmucosally identified (Figure $1 \mathrm{~A}$ ). The lacrimal bone and nasal mucosa were evaporated using a laser with 8-12 W of power and a 450-ms pause between pulses. The osteotomy diameter sizes were approximately $8 \mathrm{~mm}$ vertically and $5 \mathrm{~mm}$ horizontally (Figure 1 B). The burned debris around the osteotomy was cleaned with forceps. The total laser energy in joules and operation time were noted. Silicon tubes were inserted into both canaliculi and tightened in the nose (Figure $1 \mathrm{C}$ ). The anatomical success was controlled by irrigating the lacrimal system in both canaliculi. Antibiotic-soaked cotton plugs were inserted into the nose and removed after 2 days at the first follow-up visit. The patients were postoperatively treated with mometasone furoate nasal spray (Nasonex; Schering-Plough, Istanbul, Turkey), q $1 \mathrm{~h}$ for 1 month, and with $0.1 \%$ dexamethasone eye drops (Maxidex; Alcon, Istanbul, Turkey) q 6 h, and $0.3 \%$ ofloxacin eye drops (Exocin; Abdi İbrahim, Istanbul, Turkey) q $6 \mathrm{~h}$ for 10 days.

The silicon tube was removed during the third month after visualizing the neo-ostium with a nasal endoscope. The patients were examined during the sixth and twelfth months to evaluate the success of the surgery. Anatomical success was defined as patency of the neo-ostium with irrigation. Functional success was defined as the absence of epiphora as indicated by the patient.

Statistical analysis was performed using the Statistical Package for Social Sciences version 15.0 (SPSS Inc., Chicago, IL).

\section{RESULTS}

Group 1 included 28 male and five female patients and group 2 included 15 male and 22 female patients. The statistical difference in gender was significant $(p<0.001)$. Differences between the groups for the duration and side of the operation, laser power, and total energy used were insignificant (Table 1).

The mean follow-up durations were $13.1 \pm 1.3$ months in group 1 and $15.9 \pm 3.6$ months in group 2 .

The anatomical and functional success rates are shown in table 2. In all three examination periods, the older patients had significantly better anatomical and functional success rates $(p<0.05)$.

Covariate analyses (ANCOVA) showed that operation duration, laser power, and total energy did not significantly affect the anatomical or functional success results during any of the examination periods ( $p>0.05)$. Similarly, logistic regression analysis showed that gender had an insignificant effect on the results ( $p>0.05)$.

\section{DISCUSSION}

In recent years, diode laser has emerged as the preferred laser for performing TCDCR. Eloy et al. first described TCDCR using a diode laser in $2000^{(10)}$. This method is cost effective and can be utilized by a single ophthalmologist. The diode laser produces a wavelength of $980 \mathrm{~nm}$ and 7-20 W of power ${ }^{(3)}$, and it can ablate bone and soft tissues without causing excessive collateral damage by using a 400-600- $\mu$ optical fiber. Variable success rates have been reported for TCDCR with diode lasers ranging from 64\% to 90\%; these values were based
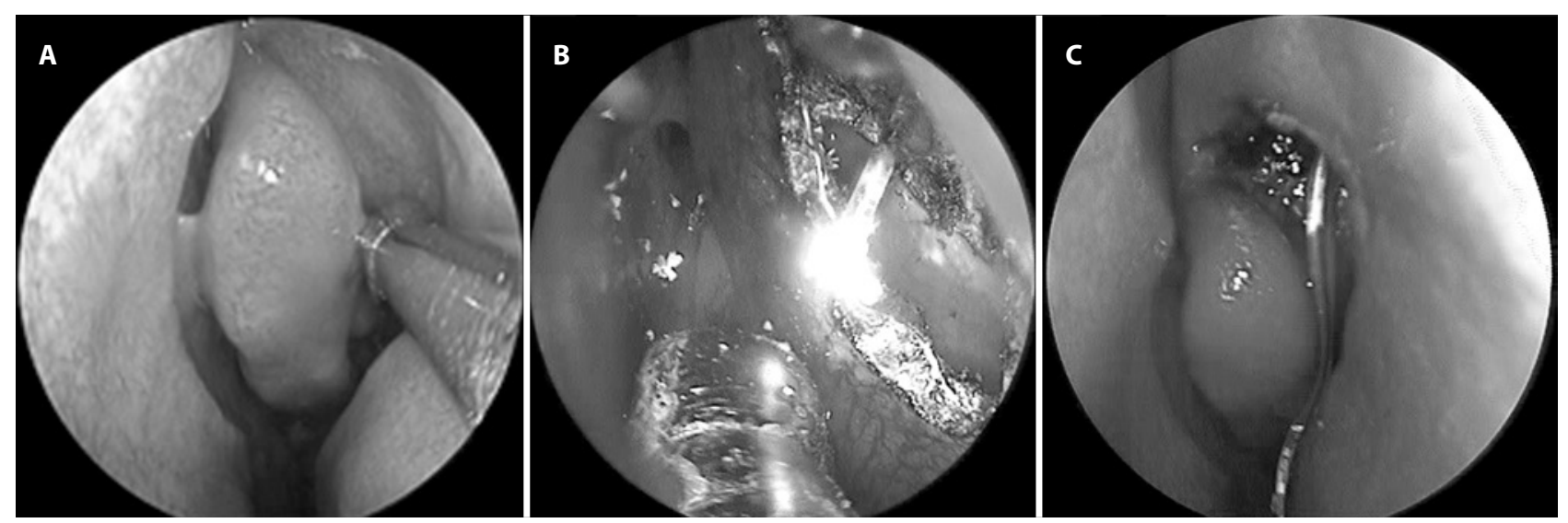

Figure 1. A) Red reflex of the laser probe at lacrimal fossa. B) Ostium created by the diode laser. C) A silicon tube passing through the ostium. 
Table 1. Differences in operation duration, laser power, total energy, and side of the operation

\begin{tabular}{|c|c|c|c|c|}
\hline & Operation duration (min) & Power (watt) & Energy (joule) & Side (right/left) \\
\hline Group 1 & $25.8 \pm 3.1$ & $10.1 \pm 1.5$ & $1037 \pm 109.4$ & $17 / 16$ \\
\hline Group 2 & $25.2 \pm 3.5$ & $10.1 \pm 1.3$ & $1074 \pm 95.9$ & $17 / 20$ \\
\hline$p$ & $0.543^{*}$ & $0.839^{*}$ & $0.139^{*}$ & $0.811+$ \\
\hline
\end{tabular}

${ }^{*}=$ independent samples $t$ test; $\dagger=$ Chi-square test.

Table 2. Anatomic and functional success ratios between the groups

\begin{tabular}{|c|c|c|c|c|c|}
\hline \multirow[b]{2}{*}{ Examination time } & \multirow[b]{2}{*}{ Group } & \multicolumn{2}{|c|}{ Anatomic success } & \multicolumn{2}{|c|}{ Functional success } \\
\hline & & Ratio (\%) & $p^{*}$ & Ratio (\%) & $p^{*}$ \\
\hline \multirow[t]{2}{*}{ Third month } & Young patients & $22 / 33(67)$ & \multirow{2}{*}{$<0.001$} & $17 / 33(52)$ & \multirow{2}{*}{$<0.001$} \\
\hline & Elderly patients & $37 / 37(100)$ & & $34 / 37(92)$ & \\
\hline \multirow[t]{2}{*}{ Sixth month } & Young patients & $15 / 33(46)$ & \multirow{2}{*}{0.001} & 15/33 (46) & \multirow{2}{*}{0.014} \\
\hline & Elderly patients & $31 / 37(84)$ & & 28/37 (76) & \\
\hline \multirow[t]{2}{*}{ Twelfth month } & Young patients & $15 / 33(46)$ & \multirow{2}{*}{0.014} & $15 / 33(46)$ & \multirow{2}{*}{0.014} \\
\hline & Elderly patients & $28 / 37(76)$ & & 28/37 (76) & \\
\hline
\end{tabular}

${ }^{*}=$ Chi-square test.

on an absence of epiphora 3 months after surgery ${ }^{(8,9)}$. However, the rates have improved over the years and have reached over $80 \%(8,10)$. Toti's classic transcutaneous approach has shown higher success rates than minimally invasive procedures, as evidenced by a wider neo-ostium and less fibrosis. This may be explained by thermal damage from the laser energy causing more fibrosis at the neo-ostium and resulting in obstruction of the nasolacrimal pathway ${ }^{(11,12)}$.

In this study, we investigated the effect of age on the success of TCDCR surgery. One of the most common reasons for TCDCR failure is stenosis and scarring of the ostium ${ }^{(7,13)}$. A patent ostium with minimal scar tissue is the most critical factor for achieving final surgical success. This study showed that clinical outcomes were worse in the younger patient group than in the patients $\geq 45$ years of age, probably due to more severe ostium fibrosis.

A recent study demonstrated that a high expression of heat shock protein 47 (a regulator of fibrosis) in scar formation was associated with the failure of endoscopic DCR ${ }^{(14)}$. Camara and Santiago reported a high rate of surgical success with the use of mitomycin $C^{(15)}$. Because the number of fibroblasts decreases or because the fibroblasts degenerate with age, milder fibrovascular proliferations can be expected in older patients, which results in less scar tissue ${ }^{(16)}$. In addition to a decline in cell number and function, diminished microcirculation contributes to poor tissue regeneration in older patients. Microcirculation provides the tissue with oxygen and supportive nutrients and regulates temperature and inflammatory responses; microcirculation can worsen with age ${ }^{(17)}$. There is further evidence to support the adverse effects of age on wound healing. Fleming et al. stated that an accumulation of methylglyoxal and increased formation of advanced glycation end products during physiological aging could result in a retardation of wound healing ${ }^{(18)}$.

In the literature, the number of studies primarily aimed at exploring the effect of age on DCR procedures has been rather small. Erdol et al. reported better external DCR results in older patients, while Kashkouli et al. found that age had no significant effect on the success of external $D C R^{(19,20)}$. Zenk et al. found that age did not have a significant effect on endonasal DCR(21), while two other studies reported that age had no effect on $\mathrm{TCDCR}^{(8,13)}$. In short, no studies have reported that age has a proven effect on endocanalicular or transcanalicular surgery. However, it is important to remember that the age differences of the groups in those studies were not as clear-cut as the age differences in this study.
In this study, we found a very significant difference in TCDCR results between the younger and older patients. At the end of the twelfth month, both functional and anatomical success rates were $46 \%$ and $76 \%$ in the younger and older patients, respectively. The success rates, regardless of age, were $88 \%, 84 \%$, and $83 \%$ in three different studies ${ }^{(8,22,23)}$. Compared with those studies, the success rate of the younger group in this study was small.

In conclusion, this study clearly showed better TCDCR results in patients $\geq 45$ years than younger patients. We believe that a possible contributing factor may be a diminished inflammatory response in the older population.

\section{REFERENCES}

1. Tarbet KJ, Custer PL. External dacryocystorhinostomy. Surgical success, patient satisfaction, and economic cost. Ophthalmology. 1995;102(7):1065-70. Comment in: Ophthalmology. 1996:103(2):200.

2. Warren JF, Seiff SR, Kavanagh MC. Long-term results of external dacryocystorhinostomy. Ophthalmic Surg Lasers Imaging. 2005;36(6):446-50.

3. Athanasiov PA, Prabhakaran VC, Mannor G, Woog JJ, Selva D. Transcanalicular approach to adult lacrimal duct obstruction: a review of instruments and methods. Ophthalmic Surg Lasers Imaging. 2009;40(2):149-59.

4. Levin PS, StormoGipson DJ. Endocanalicular laser-assisted dacryocystorhinostomy. An anatomic study. Arch Ophthalmol. 1992;110(10):1488-90.

5. Silkiss RZ, Axelrod RN, Iwach AG, Vassiliadis A, Hennings DR. Transcanalicular THC:YAG dacryocystorhinostomy. Ophthalmic Surg. 1992;23(5):351-3.

6. Hong JE, Hatton MP, Leib ML, Fay AM. Endocanalicular laser dacryocystorhinostomy analysis of 118 consecutive surgeries. Ophthalmology. 2005;112(9):1629-33.

7. Henson RD, Henson RG Jr, Cruz HL Jr,Camara JG. Use of the diode laser with intraoperative mitomycin C in endocanalicular laser dacryocystorhinostomy. Ophthal Plast Reconstr Surg. 2007;23(2):134-7.

8. Plaza G, Betere F, Nogueira A. Transcanalicular dacryocystorhinostomy with diode laser: long-term results. Ophthal Plast Reconstr Surg. 2007;23(3):179-82. Comment in: Ophthal Plast Reconstr Surg. 2008;24(3):245; author reply 245.

9. Rosen N, Barak A, Rosner M. Transcanalicular laser-assisted dacryocystorhinostomy. Ophthalmic Surg Lasers. 1997;28(9):723-6.

10. Eloy P, Trussart C, Jouzdani E, Collet S, Rombaux P, Bertrand B. Transcanalicular diode laser assisted dacryocystorhinostomy. Acta Otorhinolaryngol Belg. 2000;54(2):157-63.

11. Harish V, Benger RS. Origins of lacrimal surgery, and evolution of dacryocystorhinostomy to the present. Clin Experiment Ophthalmol. 2014:42(3):284-7.

12. Anijeet D, Dolan L, Macewen CJ. Endonasal versus external dacryocystorhinostomy for nasolacrimal duct obstruction. Cochrane Database Syst Rev. 2011. CD007097.

13. Kaynak P, Ozturker C, Yazgan S, Karabulut GO, Akar S, Demirok A, et al. Transcanalicular diode laser assisted dacryocystorhinostomy in primary acquired nasolacrimal duct obstruction: 2-year follow up. Ophthal Plast Reconstr Surg. 2014;30(1):28-33. 
14. Smirnov G, Pirinen R, Tuomilehto H, Seppa J, Terasvirta M, Uusitalo H, et al. Strong expression of HSP47 in metaplastic nasal mucosa may predict a poor outcome after primary endoscopic dacryocystorhinostomy: a prospective study. Acta Ophthalmol. 2011:89(2):e132-6

15. Camara JG, Santiago MD. Success rate of endoscopic laser-assisted dacryocystorhinostomy. Ophthalmology. 1999;106(3):441-2. Comment in: Ophthalmology. 2000 107(1):4-5. Comment on: Ophthalmology. 1998;105(6):1106-13.

16. Sato K, Hirano M. Age-related changes of the macula flava of the human vocal fold. Ann Otol Rhinol Laryngol. 1995;104(11):839-44

17. Bentov I, Reed MJ. Anesthesia, microcirculation, and wound repair in aging. Anesthesiology. 2014;120(3):760-72

18. Fleming TH, Theilen TM, Masania J, Wunderle M, Karimi J, Vittas S, et al. Aging-dependent reduction in glyoxalase 1 delays wound healing. Gerontology. 2013;59(5):427-37.
19. Erdol H, Akyol N, Imamoglu HI, Sozen E. Long-term follow-up of external dacryocystorhinostomy and the factors affecting its success. Orbit. 2005:24(2):99-102.

20. Kashkouli MB, Parvaresh M, Modarreszadeh M, Hashemi M, Beigi B. Factors affecting the success of external dacryocystorhinostomy. Orbit. 2003;22(4):247-55.

21. Zenk J, Karatzanis AD, Psychogios G, Franzke K, Koch M, Hornung J, et al. Long-term results of endonasal dacryocystorhinostomy. Eur Arch Otorhinolaryngol. 2009;266(11): 1733-8.

22. Yeniad B, Uludag G, Kozer-Bilgin L. Assessment of patient satisfaction following external versus transcanalicular dacryocystorhinostomy with a diode laser and evaluation if change in quality of life after simultaneous bilateral surgery in patients with bilateral nasolacrimal duct obstruction. Curr Eye Res. 2012:37(4):286-92.

23. Ozcimen M, Uysal IO, Eryilmaz MA, Kal A. Endocanalicular diode laser dacryocystorhinostomy for nasolacrimal duct obstruction: short-term results of a new minimally invasive surgical technique. J Craniofac Surg. 2010;21(6):1932-4.

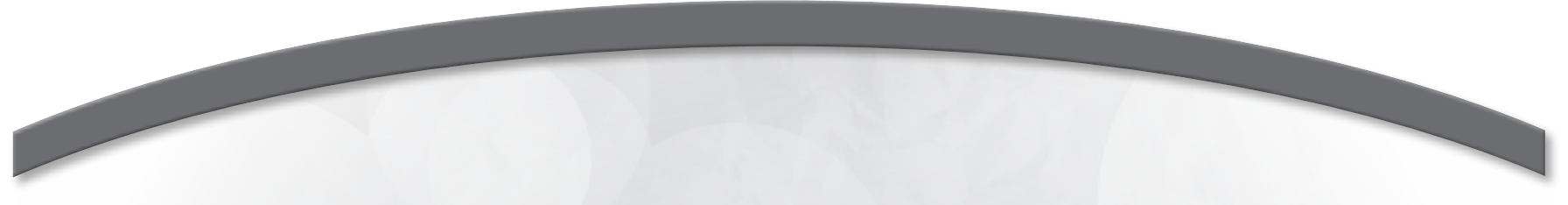

$18^{\circ}$ Congresso de Oftalmologia da Clínica Oftalmológica da FMUSP

\section{$17^{\circ}$ Congresso de Auxiliar de Oftalmologia}

\section{4 e 5 de dezembro de 2015}

São Paulo - SP

Informações:

Site: www.oftalmologiausp.com.br 